\title{
Review Paper on University Teachers Performance Appraisal
}

\author{
Awol Ahmed Mohammed \\ Department of Educational Planning and Management, College of Education and Behavioural Studies, Madda Walabu University, \\ Bale Robe, Ethiopia \\ Email: awol.ahamed@yahoo.com
}

How to cite this paper: Mohammed, A.A. (2020) Review Paper on University Teachers Performance Appraisal. Open Access Library Journal, 7: e6509.

https://doi.org/10.4236/oalib.1106509

Received: June 9, 2020

Accepted: July 25, 2020

Published: July 28, 2020

Copyright (C) 2020 by author(s) and Open Access Library Inc.

This work is licensed under the Creative Commons Attribution International License (CC BY 4.0).

http://creativecommons.org/licenses/by/4.0/

\section{(c) (i) Open Access}

\begin{abstract}
The purpose of the review paper is to summarize and analyze the previously published articles on the university teachers' performance appraisal. The researcher reviewed different articles on the title stated above. The primary aim of university performance evaluation system should be institutional improvement through quality assurance in every process of action. Teachers' job performance assessment criteria should be objective with complex judgment of work performance. The assessment should be based to improve credibility of performance assessment. Feedback from immediate supervisors, colleagues and students is helpful to strengthen the professional development of university teachers.
\end{abstract}

\section{Subject Areas}

Education

\section{Keywords}

University Teachers, Performance Appraisal, Performance Management, Assessment Criteria

\section{Introduction}

The paper of this study reviewed, discussed, summarized and analyzed 12 (Twelve) articles on "University teachers performance appraisal". The review focused mainly to review key articles and literatures that are connected with performance assessment. The paper stated briefly the method with the strategy that the researcher reviewed different published articles by summarizing and analyzing the content issues. The discussion section mainly emphasized: the democratic impacts of evaluators, reward systems and benefits and assessment crite- 
ria. Moreover conclusion of the work, significance and contribution of the review and the shortcomings for further research is clearly stated.

Evaluating teachers performance is often difficult and subjective. Performance Appraisal is a formal system that evaluates the quality of teachers' performance [1]. It is a process of measuring and developing the individual and the team performance; a set of performance management or appraisal practices with goal setting and planning, monitoring and feedback, appraising and remunerating of employees [2]. According to [3] performance appraisal has become a term used for a variety of activities through which organizations seek to assess employees and develop their competence, improve performance and allocate rewards. Here it is important to disclose that there are abundant studies regarding performance appraisal, performance review, performance evaluation, performance assessment, performance employee, staff assessment and service rating [4]. Furthermore, performance appraisal can be defined as the ongoing process used for identifying, measuring and developing an individual's performance with an organization's strategic goals [5]. One can infer from this that the term performance appraisal is multidimensional and related with multi-dimensional activities. It has a lot to do with the quality of teachers, to assess employees' competence and performance. It is an organizational process that is based to identify performance and institutional strategic goals.

The aim of this paper is to review and discuss some of the key resources connected with teachers' performance appraisal. The options that are given by the researchers will be indicated in the paper and further direction will be given. Challenges and opportunities offered by performance appraisal will be discussed. According to [6] the intensity of change quickens and the emphasis of keeping up with it heightens. Greater transparency demands that school system can compete and emerge in the global economy. In line with this [7] state, an effective performance system will adhere to meeting demands by hiring employees accountable, addressing under performance and practice. Performance appraisal provides feedback to employees about their performance, facilitating decisions concerning pay increases, promotions and layoffs, encouraging performance improvements, setting and measuring goals, determining individual and organizational training needs, improving overall organizational performance and ethical needs to bring the education to a higher level of performance [8]. The primary aim of a university performance evaluation system should be institutional improvement through quality assurance in every process of action. Ranking systems could supplement the evaluation procedures undertaken by the necessary officials [9]. Several researchers have identified the impacts of the personal and social attributes of teachers, students and administrators which affect their attitudes toward each other [10]. According to [11] teaching performance is related to the number of students, degrees awarded and the quality of education provided. Primary performance measures can only be applied at the organizational level. Individual instructors are responsible for the quality of education provided in the delivery of the courses they teach. 


\section{Materials and Methods}

The researcher reviewed different articles on the issue of university teachers' performance appraisal. The articles reviewed are twelve in number. The key words and the database of each of the articles are given at the end of the study. $\mathrm{P} / \mathrm{s}$ see Appendix one. Article review summarizes and analyzes previously published studies rather than reporting new facts and producing new information. Due to this reason, the researcher has not collected new data or instruments and no need to identify sampling techniques. Rather, the researcher reviewed primary literatures on the topic. The articles reviewed are twelve in number. Detail information about the authors, the title of each of the articles and full information of each of the papers are given at the end of the study. P/s see Appendix 1. Accordingly, narrative thematic analysis was given on the revised articles making summary, analysis and conclusion.

\section{Discussion}

It is apparent that the role of research and teaching in universities has long history. University was a place of teaching of universal knowledge, attitude and skills. It is objective is to disseminate knowledge, competence, technology, science and scientific discovery. The general management literature advocates that to secure effective implementation strategy and organization performance measures should be aligned with its strategic objectives. Teaching quality/effectiveness is usually gauged via student assessments. Although the use of student assessment is controversial, much of the literature in the area concludes that student assessments are generally consistent and relevant [12] [13]. These major determinants of accuracy are rater motivation, rater ability and availability of appropriate judgmental norms. Long been, employee performance been regarded as an important part of management function, for the purposes of salary increment, administrative purposes and recognizing future management potential. The study by [14] comes across the finding of his research that failure to adhere to the "applicant flow technique" of adverse impact administration, interest in assessing performance appraisal systems regardless of their adverse impact and ignorance regarding acceptable validation procedures and focus on objectivity.

\subsection{Demographic Impacts on the Evaluators}

In any university and other professional organizations either governmental or private better skills professionals are required desperately by the universities and the labor market. Without smart management skilled human resources, academic planning and proper management, it would be difficult to implement skillful performance appraisal. The provision of performance information for the concerned bodies should not be underestimated. The ranking systems could supplement the evaluation procedures undertaken by official actors. One of the significant developments in the technology performance management has been 
the identification of specific "Core competencies" by the organizations. Competencies are critically important for all members of the organizations behaviors, skills, attributes, performance factors and proficiencies that every organization member is expected to possess and display [15] [16].

The author of this paper shares the view of those authors in such a way that vertical evaluation is not the issue of few personnel in the universities; it should be the entire concern of the community of the universities. With the present global technological development, various issues of performance appraisal, such as competency level assessment, genuine, fairness, truth and openness should be developed. The outlook of subjective appraisal should be minimized and it should be based on the overall skillful strategic planning. The impact relationship between administrators, teachers and students should not be undermined. It is the agreement of many researchers that not only personal attributes of teachers, administrators and students but also contextual factors affect the evaluation process of the evaluators. Attitudes of teachers and students can be influenced by contextual variables of the immediate school context and classroom [17] [18] and [19].

It is apparent, that higher education is important with the phenomena of global technology. Higher educations are the centers of teaching learning, research and community service. The vision and mission of most of the universities is similar in such a way to promote high quality teaching learning, institutional excellence, competence based evaluation and advanced goal oriented performance appraisal. Teachers' evaluation is an essential outset to determine the performance of each and every faculty member and the whole community within the university. Performance management and quality enhancement ultimately rely on human resource interventions and both chase the goal of delivering better services. The prior development of any system for university performance practice should be based on the preparation of clear content and the meaning of quality, equity and efficiency.

Comprehensive performance appraisal of teachers should not be based solely on a ranking system. It should as well reflect more reliable and useful that can provide more reliable, useful and value added that can provoke international competence [20]. Subordinates and co-workers ratings are particularly variable, due to their importance to provide different and significant perception on rates skill and behavior. Faculties and departments self-evaluation is more useful as compared to other methods to reflect the weak aspects of instruction and the skills of classroom appraisal. Feedback would become more reliable when information is gathered from different sources such as teachers, students oneself and also from the community in general.

The argument from [21] states, self-direction leads a teacher towards a passion for learning and strong individual responsibilities. Effective teachers can see themselves through self-evaluation while they are actually doing on the process of teaching. Administrators are the key role model for the efficiency punctuality of performance appraisal. High level administrators', faculty and department 
heads are critically responsible for well deep rooted performance appraisal. Information should not be only gathered from one or two sources, it should be also collected from various sources. The concerned evaluators, especially administrative heads, teachers and others should be free from unethical, biased and illegal appraisal implementation. When performing the issue of performance appraisal, attitude differences in ethnicity, race, socioeconomic, gender, language and geographical area should be taken into account critically. Performance must be based on justice and proper democratic outlook. Moreover, performance appraisal would be more proper and efficient if it is based on scientific theoretical framework and model based activities.

\subsection{Reward Systems and Benefits}

Performance management of academic staff is based on performance appraisal and remuneration decision. Performance management/approval are considered as an important management on tactical levels. Performance appraisal of academic staff may be position-based and/or annual general and or detailed, long- or short term, quantitative and/or qualitative indicator based, objective and/or subjective and combination of all the above. Performance management enables the consolidation of work effort of individuals and work teams to achieve strategic goals of organization. It is clear that the goal of performance appraisal is to give evaluation to work results and provide feedback for further development of work performance. The central aim of performance appraisal systems where workout puts or results of appraisal connected to employees' salary is to ensure increased work motivation and thus improve results on individual or organizational/institutional level. This has been emphasized in several different motivational theories such as goal-setting theory, expectancy theory and most dominant of them agency theory [22] [23] and [24].

The educational leaders are expected to follow a consistent performance management process that serves the interest of their institutions that can enhance employee development. Performance management is helpful to improve work relationship, improve organizational performance, improve organizational culture, and minimize bias and subjectivity. The performance appraisal may be ineffective unless it is being linked to performance enhancing policies. If performance appraisal is used in isolation, it may not yield the desired outcomes. Performance appraisal must be the entire culture of the university culture. If properly applied, it can give constructive feedback and if not that can induce employee demonstration, turnover intention and unproductive behaviors from the employees [25] [26] [27] and [28].

In general, performance approval is helpful to identify overall performance, develop assessment measure and collect performance information from different sectors of colleges in the university and to evaluate performance attentively. Hence it is of crucial importance for salary increase, assessment based promotion and to give proper and valid feedback to teachers. This motive can bring concrete motivation that can indicate teachers to better performance. 


\subsection{Assessment of Working Performance (Assessment Criteria)}

With the present global world performance assessment criteria are considered to be an important aspect of enhancing evaluation activities. In Slovak Republic universities, assessment criteria are based on the accepted aims, knowledge, skills, attitudes, value orientation, creativity, motivation and other characteristics. Ensuring the quality of university education is repeatedly occurring topic of professional and laic community not only in Slovakia, but also in the whole world. In the USA the quality of universities is evaluated according to the actual results such as Top American universities (TARU) evaluation model that use indicators to gauge such areas as the quality of research and the teaching learning competence of graduates and undergraduates [29]. The current state of teachers' performance assessment in the University of Zilinia, that is located in the North West region of Slovak Republic is sustaining and enhancing quality in all its academic and supporting activities. For the quality assurance the, University of Zilinia (UNIZA) uses the internal quality assessment systems and external quality assessment carried out especially by independent certified/accredited organizations. The aim of the assessment is to acquire information about achieved job performance for the purpose of creating conditions of higher motivation and more effective work of university teachers in future. On the bases of the assessment the employees obtain information about their performance from the view of their immediate direct supervisors. The information should be a base and helpful for the future working orientation and to minimize the faults that arise within the work conditions [30]. Concerning the quality of any subject and teacher, students should have also opportunity to express their opinion through the enquiry that is part of academic information and educational system of UNIZALA. In this case the results are evaluated by the teachers giving the lessons and head of the departments (Table 1).

Table 1. Form of the university teacher performance assessment (UNIZA, 2003).

\begin{tabular}{|c|c|c|c|c|}
\hline Assessment criteria & & sse & me & \\
\hline 1. The extent of using knowledge and experience in practice & 1 & 2 & 3 & 4 \\
\hline 2. Concern for own professional growth and personable development & 1 & 2 & 3 & 4 \\
\hline 3. Performance of the tasks in education and in the field of science and research & 1 & 2 & 3 & 4 \\
\hline 4. Production of study materials and their professional level & 1 & 2 & 3 & 4 \\
\hline 5. Ability of quick adaptation to changed conditions & 1 & 2 & 3 & 4 \\
\hline 6. Independence and initiative in performance of the work tasks & 1 & 2 & 3 & 4 \\
\hline 7. The level of scientific-research and publication activity & 1 & 2 & 3 & 4 \\
\hline 8. Applying new forms and methods in education & 1 & 2 & 3 & 4 \\
\hline 9. Active participation in international events and participation in their preparing & 1 & 2 & 3 & 4 \\
\hline $\begin{array}{l}\text { 10. Personable elements in relation to work and performance of the tasks } \\
\text { (Reliability, consequentiality, work in team, efficiency, work discipline and, etc.) }\end{array}$ & 1 & 2 & 3 & 4 \\
\hline
\end{tabular}

Sum 
The background for the complex assessment of the university teachers' job performance assessment in the survey activities and outputs of the pedagogical employees of the UNIZA that is early updated and approved. Some of the dissatisfaction of the teachers with job performance assessment at the University of Zilinia [31] was described as the following:

- The assessment was very subjective according to the teachers.

- Specified criteria were very general, immeasurable and unclear.

- Exact specification of criteria and assigning the weights were missing

- The expects of results on evaluated teachers were doubted.

- Exact specification of the subject competent to evaluate the job performance was missing.

- The form has limitation that it could not be used as a base comparison of individual performance.

In Bucharest, Romania; the University of Titu Maiorescu, Caleta Vocaresti 187 evaluation criteria for performance approval of faculty members is an interdisciplinary study situated in between the concern for the quality of the evaluation process and efficient human resource management. Teachers Performance evaluation are particularly valuable because it provides difference and significant perspectives on rates skill and behavior and it informs people about the effect their action and workplace [32]. The literature is abundant in studies regarding performance appraisal, performance review, performance evaluation, performance assessment, performance measurement, employee evaluation, personal review, staff assessment and service rating [33]. Most of them refer to the service organizations. The high-placed evaluation of science and technology, the implementation of new technology and the globalization competitive market enhance the need for evaluation of personnel inside organization [34].

\section{Ethiopian universities job performance assessment}

The researcher for this review paper is working in one of the Ethiopian university by the name Madda Walabu. Through long years of his personal experience (not less than 30 years), he had visited some of the universities. He has checked also the document report of some of the universities. Almost all are using the standard format from the government directed by the Federal Ministry of Education of Ethiopia. The assessment criteria were set centrally that the teachers of the universities should be assessed by the students, colleagues of the teachers and the department heads of the university. The maximum value was given to the students (50\%), the next lower value for the colleagues (30\%) and the least value (20\%) to the department heads or the administrative officials.

For the sake of convenience, the reviewer of this paper has separated the student format that is used by Madda Walabu University in Ethiopia into two distinctive parts. Those items that are expected that students can easily understand them to assess their teachers are stated under Table 2(a) and those items that are difficult to assess in line with the standard level of the students are labeled under Table 2(b). One can infer from Table 2(a) that the assessment items are open 
Table 2. Teachers evaluation format by students (value given 50\%).

(a)

Dear student. Please check in the boxes indicating how you evaluate your teachers for this semester altogether.

Date: Your field of study

Year

Your gender

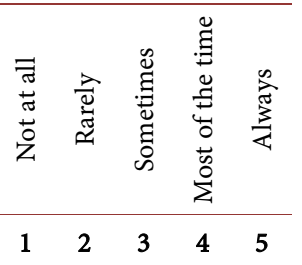

\section{Satisfaction with the teacher's teaching abilities}

$1.1 \mathrm{He} / \mathrm{She}$ makes good preparation

$1.2 \mathrm{He} / \mathrm{She}$ uses various techniques of teaching

$1.3 \mathrm{He} / \mathrm{She}$ motivates students to exercise

$1.4 \mathrm{He} /$ She gives exclusive supports based on students' performance

$\begin{array}{lllll}1 & 2 & 3 & 4 & 5 \\ 1 & 2 & 3 & 4 & 5 \\ 1 & 2 & 3 & 4 & 5 \\ 1 & 2 & 3 & 4 & 5\end{array}$

\section{Satisfaction with teacher's relationship behaviors}

$2.1 \mathrm{He} / \mathrm{She}$ gives due respect and recognition to each student

2.2 He/She makes no discriminations among students

2.4 He/She is open to share his/her experience for new things and ideas

$2.5 \mathrm{He} /$ She recognizes individual differences and needs

$\begin{array}{lllll}1 & 2 & 3 & 4 & 5\end{array}$

$2.6 \mathrm{He} / \mathrm{She}$ demonstrates exemplary behaviors

$2.10 \mathrm{He} / \mathrm{She}$ shows care toward students

$2.11 \mathrm{He} / \mathrm{She}$ shows impartiality

$\begin{array}{lllll}1 & 2 & 3 & 4 & 5\end{array}$

$\begin{array}{lllll}1 & 2 & 3 & 4 & 5\end{array}$

$\begin{array}{lllll}1 & 2 & 3 & 4 & 5\end{array}$

Source: The Federal Democratic Republic of Ethiopia Ministry of Education (May 29/2018), Ethiopia.

(b)

Dear student. Please check in the boxes indicating how you evaluate your teachers for this semester altogether.

Date: Your field of study

Year

Your gender

\section{Satisfaction with the teacher's teaching abilities}

$1.5 \mathrm{He} /$ She assesses student's abilities using multiple techniques

$\begin{array}{lllll}1 & 2 & 3 & 4 & 5 \\ 1 & 2 & 3 & 4 & 5 \\ 1 & 2 & 3 & 4 & 5 \\ 1 & 2 & 3 & 4 & 5 \\ 1 & 2 & 3 & 4 & 5 \\ 1 & 2 & 3 & 4 & 5\end{array}$

1.6 He/She demonstrates passion and interest in teaching

$1.7 \mathrm{He} / \mathrm{She}$ uses practical examples/cases from the real world

$1.8 \mathrm{He} / \mathrm{She}$ presents his/her personal research and consultancy experiences

$1.9 \mathrm{He} / \mathrm{She}$ encourages pragmatism

$1.10 \mathrm{He} /$ She triggers thinking

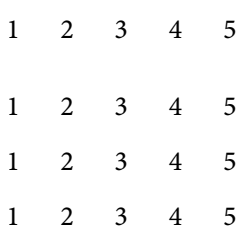

\section{Satisfaction with teacher's relationship behaviors}

$2.3 \mathrm{He} / \mathrm{She}$ sets and communicates criterion/expectations and assessments clearly

$2.7 \mathrm{He} /$ She promotes equality

$2.8 \mathrm{He} / \mathrm{She}$ demonstrates devotion to purpose

/2018), Ethiopia. 
enough and students can easily understand to at least assess their respective teachers.

The table depicts that the maximum value is given to the students (50\%). The reviewer of this paper has reservation on the value that was given to the students. The concerned bodies should further assess various assessment and psychological maturity level models that is pertinent to the standard level of the students.

The reviewer of this paper has identified the items under Table 2(b) as difficult and complex that students cannot understand them easily to assess their teachers easily. Some of the words such as multiple techniques (under item 1.5), passion (under item 1.6), real world (under item 1.7), research and consultancy experience (under item 1.8) and pragmatism (under item 1.9) are complex professional terms that are beyond the experience level of the students. Since the students cannot understand the terms, rather it would be difficult for the students to assess their respective teachers.

Similarly the items identified and stated in the above tables call for further revision. Assessment is not a simple issue that can be performed with random and unorganized trial and error. It needs further investigation and critical analysis of research based phenomena.

Madda Walabu University Instructors' Performance Evaluation Checklist (To be completed by colleagues) (Value given $30 \%$ )

For the sake of convenience the researcher has adjusted the items in Table 3 by taking the most important once. The total number of items that ought to be in the table were twenty, but reduced to thirteen items. The most important once are taken into consideration. As it can be seen from the table below (Table 3) the next comparative value is given to the colleagues is (30\%). Next to the students the next comparative value is given to the colleagues of the teachers. As such the reviewer doesn't have any reservation on the assessment level and value given to the colleagues of the teachers.

Teachers and colleagues are within the same staff community that one teacher can easily identify the behavior, cognitive, ethics and approach of the fellow friends. The issues stated in Table 3, such as preparing teaching materials, updating the subject matter and willing of the teacher towards serving the community can easily be identifiable by the fellow friends.

Madda Walabu University Instructors' Performance Evaluation Checklist (To be completed by Immediate Supervisor) (Value given 20\%)

The researcher has summarized the items in Table 4 from twenty to eleven. Most important and relevant once are taken. The rest omitted are almost similar to those that are taken into account. The Table indicates that the value given to the supervisors is $20 \%$, which is the lowest when compared to the level of value that is given to the students and the colleagues. The reviewer of the paper assumes that the highest value as far as $50 \%$ should be given to the immediate supervisors not to the students.

Supervisors are the highest body to monitor and control the duty of teachers' 
Table 3. Instructors' performance evaluation. $1=$ Very Low (VL) $2=$ Low (L) $3=$ Average (A) $4=$ High (H); 5 = Very High (VH) "Not Applicable”.

\begin{tabular}{lllllllll}
\hline & \multicolumn{1}{c}{ Evaluation Criteria } & \multicolumn{5}{c}{ Scale } \\
\cline { 3 - 7 } No & VL & L & A & H & VH & NA \\
\hline Core Competency: Subject matter & & & & & & \\
1 & Contribution in preparing and searching for teaching materials & 1 & 2 & 3 & 4 & 5 & NA \\
2 & Continuous update of the subject matter & 1 & 2 & 3 & 4 & 5 & NA \\
3 & Level of his/her subject matter knowledge and skill & 1 & 2 & 3 & 4 & 5 & NA
\end{tabular}

\section{Core Competency: Research and Community Services}

Willingness and level of engagement in community service and volunteer activities

$\begin{array}{llllll}1 & 2 & 3 & 4 & 5 & \mathrm{NA}\end{array}$

Identifying priority areas in one's discipline and pursuing research

5 in that area and Willingness to help colleagues in identifying areas of research and proposal development

\section{Professional Competency}

6 Participation in problem identification and solving at department/college/institution

7 Participation in Comprehensive Continuous Professional Development /CCPD, HDP, ELIP

8 Willingness to actively participate in cooperative learning and team teaching activities and preparedness to implement change tools

\section{Ethical Competency}

9 Willingness to share university resource with other colleagues

$\begin{array}{llllll}1 & 2 & 3 & 4 & 5 & \mathrm{NA}\end{array}$

10 Having positive attitude to work with others (team spirit)

$\begin{array}{llllll}1 & 2 & 3 & 4 & 5 & \mathrm{NA}\end{array}$

11 Level of respect to rules, regulations and guidelines of the institution

Time Management

12 Time management in department Affairs and in teaching learning

12 activities

$\begin{array}{llllll}1 & 2 & 3 & 4 & 5 & \mathrm{NA}\end{array}$

13 Time utilization for consultation hours

$\begin{array}{llllll}1 & 2 & 3 & 4 & 5 & \text { NA }\end{array}$

Total

Source: The Federal Democratic Republic of Ethiopia Ministry of Education (May 29/2018), Ethiopia.

Table 4. Immediate supervisor performance evaluation. $1=$ Very Low (VL) $2=$ Low (L) 3 = Average (A) 4 = High (H); 5 = Very High $(\mathrm{VH})$ "Not Applicable".

\begin{tabular}{|c|c|c|c|c|c|c|c|}
\hline \multirow{2}{*}{ No } & \multirow{2}{*}{ A. Evaluation Criteria } & \multicolumn{6}{|c|}{ Scale } \\
\hline & & VL & $\mathrm{L}$ & A & $\mathrm{H}$ & $\mathrm{VH}$ & NA \\
\hline \multicolumn{8}{|c|}{ Core Competency } \\
\hline 1 & Efforts of self-development in his/her specialization & 1 & 2 & 3 & 4 & 5 & NA \\
\hline 2 & Adequacy of subject matter knowledge & 1 & 2 & 3 & 4 & 5 & NA \\
\hline 3 & $\begin{array}{l}\text { Willingness to accept additional teaching assignments when } \\
\text { compelling situation arises in the department }\end{array}$ & 1 & 2 & 3 & 4 & 5 & NA \\
\hline
\end{tabular}




\section{Continued}

Active participation in improvement of teaching-learning process,

$\begin{array}{llllllll}4 & \text { seminars. workshop, symposia and reviewing of teaching materials } & 1 & 2 & 3 & 4 & 5 & \text { NA }\end{array}$ (curriculum)

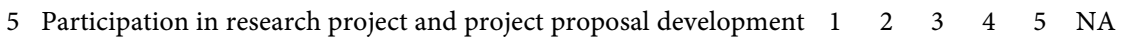

\section{Professional Competence}

6 Participation in problem identification and solving at

department/college/institution

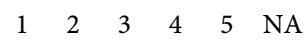

7 Continuous assessment implementation

Time Management

8 Executing assigned classes/invigilation on time.

9 Notifying and implementing consultation timely and Giving timely

feedback to students

$\begin{array}{llllll}1 & 2 & 3 & 4 & 5 & \mathrm{NA}\end{array}$

\section{Ethical Competence}

Showing concern for the use of resources of the department and the University

11 His/her professional ethics and being a role model (dressing, hair

style, personality, addiction...)

Total

Source: The Federal Democratic Republic of Ethiopia Ministry of Education (May 29/2018), Ethiopia.

best, such as daily effort of teachers, adequacy of the subject matter and his/her competency to the subject knowledge. The other issues such as the approach of the teachers towards problem solving and time management can easily be identified by his/her colleagues.

Supervisors are the main bodies to monitor and control the duty of teachers that is based on the university vision, mission and strategic plan. They are the formal body assigned by the government and the university to follow and regulate the teaching learning, research and community service of the university. This does not mean that the students should not assess the teachers. According to the researcher, almost $25 \%$ could be enough as regard to the age and maturity level of the students. Whatever so, this is personal comment from the reviewer.

\section{Conclusions}

Performance appraisal is a process of measuring and developing the individual and team performance. The set of performance management appraisal practices with goal setting, monitoring, feedback and remunerating employees. The primary aim of the university performance evaluation system should be institutional improvement through quality assurance in every process of action. The aim of the review paper is to discuss some of the important researches that are connected with teachers' performance appraisal. With negative condition of demographic situation and decreased availability of resources for higher education, the budgets of universities and their subunits are under strain. Using complex and detailed performance management systems, academic staff activities can be 
shaped and managed in a more robust way.

Teachers' job performance assessment criteria should be objective and with complete judgment of work performance. The assessment should be based to improve credibility of performance assessment. Feedback from supervisors, colleagues and students contributes to strengthening professional personal development. Fair assessment with increased motivation can enhance quality of education at the university level. Satisfied and motivated teachers with quality job performance are critically important for the university teaching learning development.

\section{The Research Significance}

The study significance and contribution are stated as of the followings:

- It aims to cast light on the overall view of university teachers performance appraisal.

- It aims to create awareness for the officials, teachers and students working with in the universities.

- It is helpful to give decision makers and researchers certain highlights for their future direction of study and investigation on performance assessment.

- The review can be helpful also for officials and experts working in Ministry of Education. Scholars can benefit from the review to extract further new knowledge, theories and methodologies.

\section{Main Contributions of the Review}

The main contribution is stated below:

- To give highlights that assessment issues must be sustainable, relevant and undeformed by prejudice and other evaluative errors.

- It can give awareness that performance appraisal must be the issue of all stakeholders and strict focus to be given for job analysis and work environment.

- It is helpful to recognize that the evaluation criteria and standards must be established on the job description of employees and the criterion must be associated with the objective and the goal of the institution.

- It can give awareness to the teachers and the concerned stakeholders that teachers must be given a chance to evaluate themselves using the proper format. It can give also feedback to teachers for better awareness.

- The study can contribute by introducing a mechanism to be developed for open discussion between appraise and appraiser.

- It is helpful to introduce the performance appraisal to be institutional and highly integrated with quality assurance.

\section{Shortcomings for Further Research}

Limitation in research is restrictions and constraints which have been put on the methodology and design of the study and exploration and that these factors may 
impact the findings of the study. Each study has its own limitation. To be more accurate research limitation should be a must for the enrichment of the study [35].

In respect of this the major limitations are:

D The review is confined to 12 articles on university teachers' performance appraisal. This could limit generalizability for most of the world universities.

$>$ The summary and analysis from the confined universities stated above may limit the depth of the information to be collected.

Although the review has its anticipated objectives it has opened up a venue for further research in such a way:

- The review could have been more useful if it was to investigate other sectors of the universities.

- The process of performance appraisal in universities is a complex process. Hence it can call upon further deeper study and analysis.

- It would have been more preferable if it is to include so many other review papers by various authors, researchers and scholars.

\section{Acknowledgements}

Above all I would like to thank Allah (God), the Sovereign, the Great for the guidance in the work of this review article. I would like to express my gratitude to all those who gave their time and assistance to the completion of this article.

\section{Conflicts of Interest}

I here declare "Review Paper on University Teachers Performance Appraisal" is my review work and that all the sources that I used have been indicated and acknowledged by means of complete references. The author is with full responsibility that could be raised and conflict of interest of ownership, ethical and financial issues.

\section{References}

[1] Dhamne, A., Jadhav, D. and Somhan Shi, M. (2017) Performance Based Appraisal System for Teachers of University/Colleges. International Research Journal of Engineering and Technology, 4, 1-4. http://www.irjet.net

[2] Aguinis, H. and Pierce, C. (2007) Enhancing the Relevance of Organizational Behavior by Embracing Performance Management Research. Journal of Organizational Behavior, 29, 139-145. https://doi.org/10.1002/job.493

[3] Fletcher, C. (2001) Performance Appraisal and Management. The Developing Research Agenda. Journal of Occupational and Organizational Psychology, 74, 473. https://doi.org/10.1348/096317901167488

[4] Murphy, K.R. and Cleveland, J.N. (1995) Understanding Performance Appraisal. Social Organizational and Goal Based Perspectives. SAGE Publications, London.

[5] Aguinis, H. (2009) An Expanded View of Performance Management. In: Performance Management. Putting Research into Action, Jossey-Bass, San Francisco, 41-44. 
[6] Day, C. (2013) The New Lives of Teachers. Routledge, London.

[7] Zbar, V., Marshal, G. and Power, P. (2007) Better Schools, Better Teachers, Better Results: A Handbook for Improved Performance Management in Your School. Australian Council for Educational Research, Melbourne.

[8] Grote, R.C. (2002) The Performance Appraisal Question and Answer Book: A Survival Guide for Managers. American Management Association, New York.

[9] Anninos, L.N. (2007) University Performance Evaluation Approaches: The Case of Ranking Systems. PhD Candidate in Business Administration, University of Piraeus, Hellas.

[10] Miankheil, A.K., Nawaz, A., Khan, S. and Wajidi, F.A. (2012) University Teachers Performance Evaluation: Investigating the Demographic Impacts on the Evaluators. https://www.researchgate.net/publication/284362808

[11] Bogt, H. and Scapens, R.W. (2012) Performance Management in Universities of Effects of the Transition to More Quantitative Measurement Systems. European Accounting Review, 21, 451-497.

[12] Bedgood, R. and Donovan, J. (2012) University Performance Evaluation. What Are We Really Measuring? Studies in Higher Education, 63, 529-547.

[13] Hattie, J. and Mash, H.W. (1996) The Relationship between Research and Teaching. A Meta Analysis. Review of Educational Research, 66, 507-542. https://doi.org/10.3102/00346543066004507

[14] Kleiman, L.S. and Durham, R.L. (1981) Performance Appraisal Promotion and Courts: A Critical Review. Personnel Psychology, 34, 103-121. https://doi.org/10.1111/j.1744-6570.1981.tb02181.x

[15] Amin, H. and Khan, A.R. (2009) Acquiring Knowledge for Evaluation of Teachers' Performance in Higher Education Using a Questionnaire. International Journal of Computer Science and Information Security, 2, 1-18.

[16] Halepota, J.A. and Irani, Z. (2010) The Impact of Organizational Antecedents on Employee Job Satisfaction. An Empirical Evaluation of Public Sector in Pakistan. Mediterranean and Middle Eastern Conference on Information Systems, Abu Dhabi, 12-13 April 2010.

[17] Aslam, H.D. (2011) Performance Evaluation of Teachers in Universities, Contemporary Issues and Challenges in Pakistan Proceedings of the 211 International Conference on Teaching, Learning and Change. International Association for Teaching and Learning (IATEL), Islamia University of Bahawalpur, Pakistan, 339-362.

[18] Wooltolk, A., Davis, H. and Pape, S. (2007) Teachers Knowledge, Beliefs and Thinking. In: Alxander, P.A. and Winne, P.H., Eds., Handbook of Educational Psychology, 2nd Edition, Lawrence Erlbaum, Mahwah, 715-737.

[19] Armstrong, M. and Baron, A. (2005) Managing Performance: Performance Management in Action. CIPD, London.

[20] Martinez, J. (2000) Assessing Quality, Outcome and Performance Management. Workshop on Global Health Workforce Strategy, Annecy, 9-12 December 2000, $1-30$.

[21] Pei, W.C. (2010) Comparative Analysis of Special Education to Teacher Training in France and Norway: How Effective, Areas Taught and Recommendation for Improvement (Master Thesis Abstract). Journal for Educators, Teaching and Trainers, 1, 87-95.

[22] We, D.M. (2010) Out of the Crisis. MIT Press, Cambridge, 507 p.

[23] Scholtes, P.R. (1993) Total Quality or Performance Appraisal: Choose One. Nation- 
ally Productivity Review, 12, 349-363. https://doi.org/10.1002/npr.4040120307

[24] Semler, R. (1989) Managing without Managers. Harvard Business Review, September-October, $10 \mathrm{p}$.

[25] Whiting, S.W., Podsakoff, P.M. and Pierce, J.R. (2008) Effects of Task Performance, Helping Voice and Organizational Loyalty on Performance Appraisal Ratings. Journal of Applied Psychology, 93, 125-139. https://doi.org/10.1037/0021-9010.93.1.125

[26] Salanova, M., Agut, S. and Peiro, J.M. (2005) Linking Organizational Resources and Work Engagement to Employee Performance and Customer Loyalty: The Mediation of Service Climate. Journal of Applied Psychology, 90, 1217-1227. https://doi.org/10.1037/0021-9010.90.6.1217

[27] Kuvaus, B. (2006) Performance Appraisal Satisfaction and Employee Outcomes; Mediating and Moderating Roles of Work Motivation. The International Journal of Human Resource Management, 17, 504-522. https://doi.org/10.1080/09585190500521581

[28] Poon, J.M. (2004) Effects of Performance Appraisal Politics on Job Satisfaction and Turnover Intention. Personnel Review, 33, 322-334. https://doi.org/10.1108/00483480410528850

[29] Hall, E.R. (2010) Symposium Perspectives on University Performance Assessment. UNN, Tokyo.

[30] Bolskova, M., et al. (2003) Management and Development of Human Potential, Applying Motivation Accent in Process of Work with People. EDIS Publisher of the University of Zilina, Zilina.

[31] UNIZA (University of Zilinia in Zilinia) (2003) Methodological Regulation No 1/2003 for Complex Job Performance Assessment of the University of Zilinia Employees. Zilinia University of Zilinia, Zilinia.

[32] Anjum, A., Yasmeen, K. and Khan, B. (2011) Performane Appraisal Systems in Public Sector Universities of Pakistan. International Journal of Human Resource Studies, 1, 41-51. http://www.macrothink.org/ijhrs

[33] Murphy, R.R. and Opre, D. (2001) Evaluator Personal Academic, Cognate, Crier Compartment. Associatia de stiinte Cognitive din Romania, Clu-Napuca.

[34] Bogathy, Z. (2007) Manual de technici si metode in psihologia muncii organizaztionala. Lasi. Polirom.

[35] Brutus, S., et al. (2013) Self-Reported Limitations and Future Directions in Scholar Reports. Analysis and Recommendations. Journal of Management, 39, 48-75. https://doi.org/10.1177/0149206312455245 


\section{Appendix 1}

The number of literatures revised (12 in numbers), keywords, and data base are stated here under:

1) Kuluno, T. (2016). Performance Management of Academic Staff and its effectiveness to teaching and research: Based on the example of Estonian University- Journal of Humanities and Social Science University of Tartu Doi: 10.3176/tr.2016.1., https://www.researchgate.net/publication /296477634.

Keywords-Performance management, Academic staff, University, Performance appraisal, remuneration, pay for performance, effectiveness

Database-The method included survey and questionnaire. Surveys of AS carried in 2013. Interviews with nine academic leaders and seven FGD members. Qualitative analysis of documents and participatory observation.

2) Simon, C. Valdo, D. and Maja, G. (2017). Research, teaching and performance evaluation in Academia: The silence of Quality Studies in Higher Education, Vol 42: 8, 1455-1473, 1455-1471 Doi: 10.1080/030075079.2015.1104659

Link: https://doi.org/10.1080/03075079.2015.1104659.

Keywords-Research productivity, Research quality, Teaching quality, Performance evaluation

Database-Cross disciplinary sample of academics within a research oriented university.

3) Miankheil et al. (2012). University Teachers performance evaluation: Investigating the democratic impacts on the evaluators Goma University Journal of Research. 28(2) December, 2012, https://www.researchgate.net/publication/284362808.

Keywords-Unit teachers, Performance evaluation evaluators, Demographic attributes

Database-Survey approach was used by selecting sample of students, colleagues and administrators through structured questionnaire and stratified sampling was used.

4) Tilahun, G. and Shambel, T. (2014). Is the pole of teacher performance appraisal in Ethiopia Rhetoric or reality? Convergence between knowledge and implementation and finding solutions from the process. Ethiopian Journal of education \& science, vol 10, No 87-108.

Key terms: Appraisal, appraiser, primary school, teacher

Database-Descriptive survey: investigating opinions of teachers, school administrators, committee members, students.

5) Balaraman, P. et al. (2018). Performance appraisal fundamentals, Practices and Challenges in public sector: Case of Adigrat Town-Ethiopia. Business ethics and leadership, vol 2, Issue 4, 18-34 ARMG publishing.

Key terms-Not given.

Database-Cross-sectional survey was used and 174 respondents were taken as sample from 1213. Questionnaire with 5 likert scale.

6) Dhamne, A. et al. (2017). Performance based Appraisal System for teachers 
of university/colleges. International Research Journal of Engineering and Technology (IRJET), 04, 1-4, www.irjet.net.

Keywords: Subjective performance appraisal, Celebrity, Bowfish algorithm

Database-Based on production model. Observation was used as qualitative analysis.

7) Elliott, K. (2015). Teacher performance appraisal: More about Performance or Development? Australian Journal of Teacher Education. 40(9), vol 4/Issue 9, 102-115. http://re.ecu.edu.au/ajte/vol40/ISS916

Key terms-Not given.

Database-Qualitative analysis of teachers and students perceptions are evaluated.

8) Mania Luskova and Maria Procedia (2013). Approaches to teachers performance Assessment for enhancing quality of education at universities Social and Behavioral Sciences. 106 (2013) 476-484. www.sciencedirect.com

Keywords-Quality, Education, Assessment, Working Performance, University

Database-Survey of the activities and outputs of each teachers. Performance assessment was done on the basis of 360 degree feedback system application.

9) Elena Arnatu and Iona panc (2015). Evaluation of criteria for performance appraisal of faculty members procedia. Social and behavioral science 203 (2015) 386-392. www.sciencedirect.com

Keywords-Performance appraisal, Performance appraisal of faculty members, Academic quality, Behaviorally anchored rating scales, Performance appraisal tool

Database-Analysis of assessment criteria. Behavioral anchors are identified for high performance. Qualitative analysis.

10) Mirado, B. (2019). Perceived effectiveness of teachers performance appraisal system in government owned Secondary Schools of Sidama Zone, Ethiopia. Journal of Education and Practice, Vol 10, No 10, 2019, 28-38, www.iiste.org.

Keywords-Nor given.

Database-Descriptive survey. 147 were selected by using systematic sampling. Survey questionnaire of both closed ended and open ended questions.

11) Rosli, M. (2017). Project management. How the effectiveness of project management lead project success. University of Malaysia Pahang, Pekan, Malaysia, www.researchgate.net/publication /319772377.

Keywords-Project management, the iron triangle

Database-Critical Pass Methed (CPM) quantitative technique in project analysis.

12) Camilleri, M.A. \& Camilleri, A.C. (2018). The performance management and appraisal in higher education. In cooper, C. Driving Productivity in uncertain and challenges times. (University of the west of England, $5^{\text {th }}$ September) British Academy of Management, UK, 1-21.

Keywords-Performance management, Performance appraisal, Balance, 
Scorecard, Higher education, Academic productivity.

Database-Semi-structured interview with academic employee to analyze opinion and perception. 